\title{
Soil Hydrologic Response to Number of Pastures and Stock- ing Density under Intensive Rotation Grazing
}

\author{
S.D. WARREN, W.H. BLACKBURN, AND C.A. TAYLOR, JR.
}

\section{Abstract}

Infiltration rate and sediment production were measured for 2 years on 3 pastures from an intensive rotational grazing system. The pastures were 32,24 , and 16 ha in size. Stocking rate was held constant but stocking density at any given point in time varied due to pasture size. Stocking densities were $0.68,0.51$, and $0.32 \mathrm{ha} / \mathrm{AU}$, respectively. Within the respective treatments, midgrass interspaces exhibited significantly higher infiltration rates and lower sediment production than shortgrass interspaces. Overall, the pasture grazed at the highest stocking density produced the lowest infiltration rates and the greatest sediment loss. However, there was no consistent trend in hydrologic responses over time and the differences appeared to be the result of random selection of a poorer condition site on 1 or 2 occasions rather than the result of stocking density. Regardless of whether the pasture grazed at the highest stocking density was in similar or poorer hydrologic condition in terms of treatment response, the data do not support the hypothesized beneficial hydrologic advantages of increased stocking density via manipulation of pasture size and numbers. Rest, rather than intensive livestock activity, appears to be the key to soil hydrologic stability. The potential for altering the length of the rest period is greatest where the number of pastures is small. Therefore, very little benefit in terms of soil hydrologic condition should be expected from large increases in the number of pastures within rotational grazing systems.

Rotational grazing of some form or another has been practiced for centuries. Transhumant or nomadic grazing is the most ancient and widely used form of rotational grazing. However, the most frequently addressed form of rotational grazing in current grazing management literature is intensive short-duration grazing. The principles of intensive rotation grazing were taught as early as the 1700 's (Voisin 1959). Much of the revised interest in this system of management centers around proposed potential for significant increases in carrying capacity (Savory 1978,1983 ).

The principal objective of most rotational grazing systems is to improve or maintain the vigor and production of the forage resource and/or improve animal production. One method of enhancing forage production is to increase available soil water through improved rainfall infiltration rate and reduced runoff loss. Some modern proponents of intensive rotational grazing have hypothesized that intense trampling activity associated with high stocking density will enhance rainfall infiltration and reduce ero-

\footnotetext{
Authors are presently rangeland watershed manager, USA-CERL, Environmental Division, P.O. Box 4005, Champaign, Ill. 61820; professor of watershed management, Department of Range Science, Texas A\&M University, College Station 77843; and superintendent, Texas Agricultural Experiment Station, Sonora 76950. At the time of research, the senior author was graduate research assistant, Department of Range Science, Texas A\&M University.

Published with approval of the Director, Texas Agricultural Experiment Station, as TA-20823.

Manuscript accepted 27 January 1986.
}

sion (Goodloe 1969, Office of Technology and Assessment 1982, Savory and Parsons 1980, Walter 1984).

Stocking density, which is a measure of grazing pressure at a given point in time, may be increased by adjusting stocking rates upward or by increasing the number of pastures within an existing rotation system. Both alternatives have been suggested (Goodloe 1969, Savory 1978, Savory and Parsons 1980). Heavy stocking rates under continuous grazing are almost universally deleterious to watershed condition, generally reducing rainfall infiltration rate and accelerating erosion (Alderfer and Robinson 1947, Blackburn 1984, Branson et al. 1981, Rauzi and Hanson 1966, Rhoades et al. 1964). Recent research has shown that the use of heavy stocking rates within rotational grazing systems is also detrimental to infiltration rate and sediment production, regardless of the system used (Gamougoun et al. 1984; McCalla et al. 1984a, 1984b; Pearson et al. 1975; Pluhar 1984; Smith 1980; Thurow 1985; Warren 1985; Weltz 1983). Some research has indicated that the incidence of heavily impacted trails may increase as the number of pastures is increased within an intensive rotational grazing system (Walker and Heitschmidt 1986). The effect that an increase in the number of pastures has on hydrologic parameters has not been addressed. The objective of this study was to evaluate infiltration rate and sediment production from pastures subjected to variable stocking density as affected by number of pastures rather than stocking rate.

\section{Study Area}

Field research was conducted during 1983 and 1984 at the Texas Agricultural Research Station near Sonora, Texas. The average growing season at the Station is $\mathbf{2 4 0}$ days and extends from March through October. Long-term average annual precipitation (19181984 ) is $609 \mathrm{~mm}$. Annual precipitation for 1983 and 1984 was 108 and $203 \mathrm{~mm}$ below average, respectively.

The physiognomy of the area is characterized by dense mottes of live oak (Quercus virginiana Mill.) with grass interspaces. The midgrass component of the grass interspaces was dominated by sideoats grama (Bouteloua curtipendula (Michx.)) and Wright's threeawn (Aristida wrightii Nash). Fall witchgrass (Leptoloma cognatum (Schult.) Chase), Texas wintergrass (Stipa leucotricha Trin. \& Rupr.), and silver bluestem (Bothriochloa saccharoides (Swartz) Rydb.) were of lesser importance. The shortgrass interspaces were predominantly common curly mesquite (Hilaria belangeri (Steud.) Nash). Honey mesquite (Prosopis glandulosa Torr.) and ashe juniper (Juniperus ashei Buccholz), 2 woody species, were scattered through the grass interspaces in a savanna-like fashion. Prickly pear (Opuntia spp. Mill.) was also abundant.

In the fall of 1982, a 376-ha 14-pasture intensive rotational grazing system was put into operation at the Station. Pastures ranged in size from 32 to $8 \mathrm{ha}$. The system was stocked with a single herd composed of a 1.63:1:1 ratio of cattle, sheep, and goats at a 
stocking rate of $8.1 \mathrm{ha} / \mathrm{AU}$, which is the recommended moderate rate for the area. The number of days of grazing per pasture per rotation cycle was dependent upon the condition of the forage resource within each pasture. During the spring and summer months, the average rotation cycle was 56 days, but slowed to as much as 74 days during the winter dormant season.

Three pastures which were 16,24 , and 32 ha in size were used for this study. The 3 pastures had a similar history of moderate, discontinuous use and were in good range condition when the rotational grazing system was implemented. They were in better condition than most other pastures and were, therefore, grazed at a heavier rate, with the number of days grazing per cycle being proportional to the size of the pasture. For example, during a 56-day cycle the 32-ha pasture was grazed for 8 days while the 24-and 16-ha pastures were grazed for 6 and 4 days, respectively. The procedure maintained a constant year-long stocking rate of 4.8 ha/ $\mathrm{AU} / \mathrm{yr}$, which is approximately $1.7 \mathrm{x}$ the recommended moderate rate. However, stocking density at any given point in time varied due to pasture size; the respective stocking densities for the 32-, 24-, and 16-ha pastures were $0.68,0.51$, and 0.34 ha/AU. This design effectively simulated 3 equally stocked 224-ha intensive rotational grazing systems, with the 32-, 24-, and 16-ha pastures representing 7-, 9-, and 14-pasture systems, respectively.

Research was conducted on Kavett silty clay soil with slopes $<3 \%$ and a depth of $250-500 \mathrm{~mm}$ overlying a fractured caliche layer and limestone substratum. The soils are of the clayeyskeletal, montmorillonitic, thermic family of Lithic Haplustolls, characterized by high shrink-swell capacity and an organic matter content $>6 \%$. When undisturbed, they are well aggregated and have an average rainfall infiltration capacity exceeding $155 \mathrm{~mm} \mathrm{~h}^{-1}$.

\section{Methods}

The pastures were sampled during 2 full rotation cycles for each of the first 2 summers following implementation of the grazing system. Each pasture was sampled 3 times per rotation cycle, once immediately prior to the introduction of livestock onto the pasture, again soon after their removal, and approximately midway through the subsequent rest period. Eight plots representing midgrass interspaces and eight representing shortgrass interspaces were sampled on each sample date at sites which were randomly selected within the appropriate pasture and soil type.

A mobile, drip-type rainfall simulator (Blackburn et al. 1974) was used to determine infiltration rate and sediment production on variable area runoff plots. Plot size averaged approximately 0.4 $\mathrm{m}^{2}$. In order to reduce variability attributable to antecedent soil water content, the plots were pre-wet by applying $105 \mathrm{~mm}$ of water at a rate of $79 \mathrm{~mm} \mathrm{~h}^{-1}$ from a mist-type nozzle under a plastic cone $0.6 \mathrm{~m}$ above the soil. The plots were then covered with plastic tarps to prevent evaporation, and gravitational water was allowed to drain. After approximately 24 hours, when the soil had drained to near field capacity, simulated rainfall was applied at a rate of 203 $\mathrm{mm} \mathrm{h}^{-1}$ for 30 minutes. The rainfall simulator produced drops 2.5 $\mathrm{mm}$ in diameter which reached $70 \%$ terminal velocity. This application rate simulated a storm with a return period of 120 years and was necessary to insure runoff from all plots. Runoff from each plot was regularly pumped into tared containers. At each 5-minute interval during the simulated rainfall event, the cumulative runoff was weighed and mean infiltration rate $\left(\mathrm{mm} \mathrm{h}^{-1}\right)$ was calculated by determining the difference between applied rainfall and the quantity of water running off the plot.

At the end of each simulated rainfall event, runoff from the plot was thoroughly mixed and a 1-liter subsample was collected. The subsample was filtered through a tared Whatman \#1 filter. Sediment remaining on the filter was oven-dried, weighed, and converted to sediment production $\left(\mathrm{kg} \mathrm{ha}^{-1}\right)$ based on the area and total runoff from each plot.

Immediately prior to each simulated rainfall event, soil bulk density and soil moisture content at a depth of $0-30 \mathrm{~mm}$ were
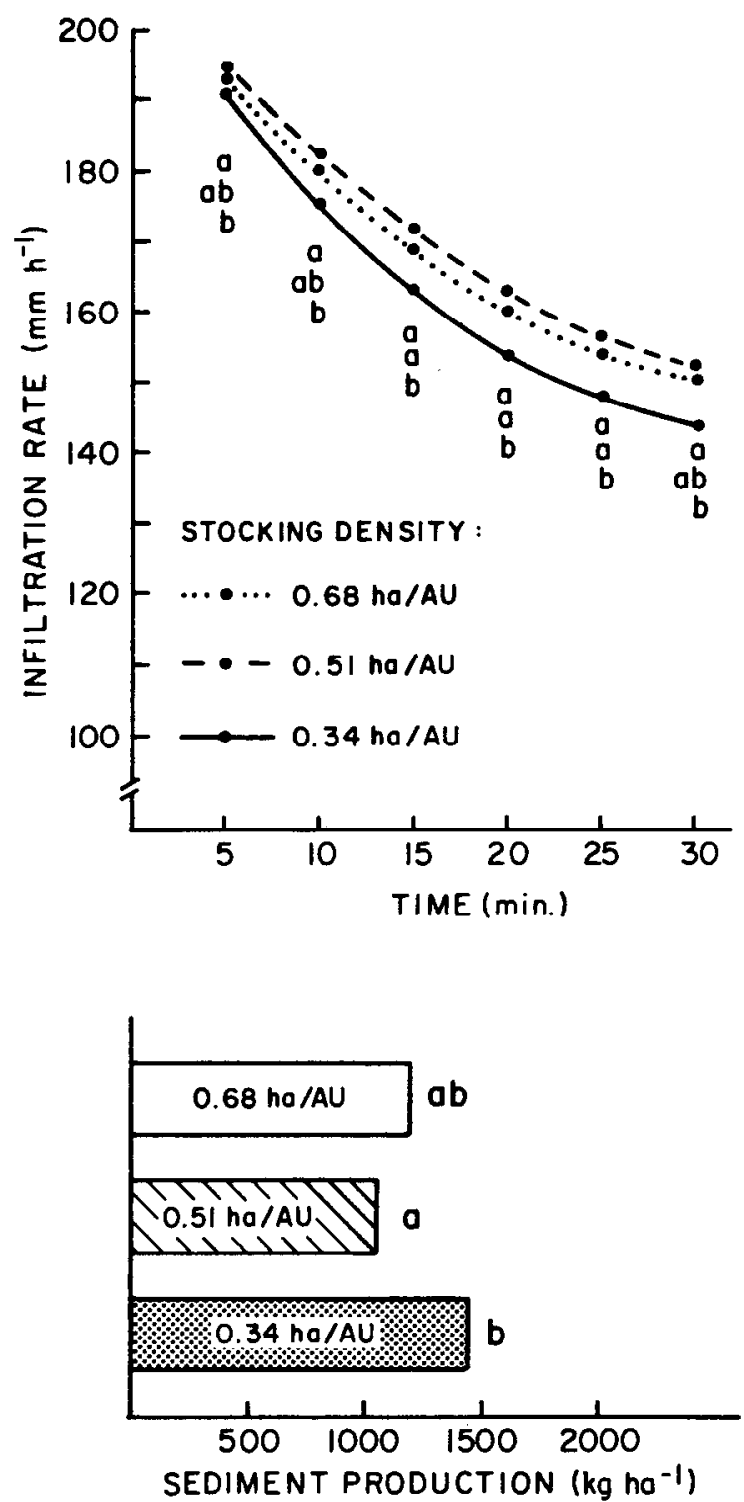

Fig. 1. Mean infiltration rate and sediment production for pastures grazed at 3 stocking densities, Edwards Plateau, Texas. Infiltration means with the same letter for the same time increment or sediment production means with the same letter are not significantly different $(\alpha=.05)$.

determined adjacent to each runoff plot by the core method (Blake 1965) and gravimetric method (Roundy et al. 1983), respectively. Soil surface microrelief within each plot was measured with a 10-pin relief meter similar to the one described by Kincaid and Williams (1966). Following simulated rainfall, a composite surface soil sample was taken to a depth of $30 \mathrm{~mm}$ from within the plot and was used for analyses of soil organic matter content by the Walkley-Black method (Nelson and Sommers 1982) and soil aggregate stability by the wet-sieve method (Kemper 1965).

Percent aerial cover of midgrasses, shortgrasses, forbs, litter, rock, and bare ground was determined by ocular estimate for each rainfall plot. Midgrass, shortgrass, and forb cover were combined to produce a single vegetative cover estimate. Following rainfall simulation, grasses and forbs were clipped to a $10-\mathrm{mm}$ stubble height and litter was hand collected from each plot. These samples were oven-dried and weighed. Grass and forb weights were combined to produce a vegetation biomass value.

Biomass variables and soil microrelief were highly skewed. $\log _{10}$ transformations were performed to meet assumptions of normal- 
ity. Analysis of variance, based on a $3 \times 3 \times 2$ factorial design, was used to determine if significant differences existed for dependent variables between trampling intensities, stages of the rotation cycle, and grass types, respectively. The error term in the analysis of variance consisted of the nested variation of the randomized sites within the factorial treatments (Snedecor and Cochran 1967). If differences were present, Duncan's multiple comparison test was used to separate the means (Steel and Torrie 1980). Simple correlation coefficients were calculated for all dependent and independent variables. A $95 \%$ level of significance was used throughout.

\section{Results and Discussion}

Mean infiltration rate was significantly greater and the amount of sediment produced was significantly less from midgrass interspaces than from shortgrass interspaces. Similar differences in hydrologic response between midgrass and shortgrass interspaces have been noted by Knight (1980), McCalla et al. (1984a, 1984b), Pluhar (1984), Thurow (1985), and Wood and Blackburn (1981a, 1981b). Significant differences were also present between stages of the rotation sequence; infiltration rate was higher and sediment production lower prior to the movement of livestock onto a pasture than after their removal, but the magnitude of the difference was dependent on seasonal climatic conditions and is reported elsewhere (Warren et al. 1986a). There was no significant interaction between any of the main factors in terms of infiltration rate or sediment production. Therefore, grass types and stages of the rotation cycle were combined for analysis of variance for stocking density.

A significant difference in mean infiltration rate occurred at each 5-min increment of the simulated rainfall event between pastures representing variable stocking density (Fig. 1). The differences were not consistent, but as a general rule, the pasture which was grazed at the highest stocking density (0.34 ha/ AU) had the lowest infiltration rate. After $30 \mathrm{~min}$ it was not significantly different from the pasture which was grazed at the lowest stocking density $(0.68$ ha/AU). The pasture which was grazed at an intermediate stocking density $(0.51$ ha/ $\mathrm{AU})$ had the highest infiltration rate, although it was not significantly different from the pasture grazed at the lowest stocking density. The same trend in hydrologic condition was true for sediment production (Fig. 1).

Logic would dictate that if stocking density were truly affecting hydrologic condition, then the pasture stocked at either the highest or lowest density would produce the highest infiltration rate and least amount of sediment. The pasture in best hydrologic condition would then be followed in sequence by the other 2 pastures, based on successively ascending or descending stocking density. Such was not the case in this study. Of the vegetation and soil variables measured, only bare ground, rock, and litter cover were significantly different between pastures (Table 1), but neither they nor other independent variables explained sufficient variability to be

Table 1. Mean vegetation and soil variables within pastures representing 3 stocking densities on the Edwards Plateau, Texas.1

\begin{tabular}{|c|c|c|c|}
\hline \multirow[b]{2}{*}{ Variable } & \multicolumn{3}{|c|}{ Stocking density } \\
\hline & $0.68 \mathrm{ha} / \mathrm{AU}$ & $0.51 \mathrm{ha} / \mathrm{AU}$ & $0.34 \mathrm{ha} / \mathrm{AU}$ \\
\hline Bare ground $(\%)$ & $27.1 \mathrm{a}$ & $26.4 a$ & $31.5 b$ \\
\hline Rock cover $(\%)$ & $2.3 \mathrm{a}$ & $3.2 \mathrm{~b}$ & $2.7 \mathrm{ab}$ \\
\hline Litter cover $(\%)$ & $26.9 \mathrm{a}$ & $28.0 \mathrm{a}$ & $23.4 b$ \\
\hline Vegetation cover $(\%)$ & $44.5 a$ & $41.8 \mathrm{a}$ & $42.4 \mathrm{a}$ \\
\hline Litter biomass $\left(\mathrm{kg} \mathrm{ha}^{-1}\right)$ & $1758.1 \mathrm{a}$ & $1739.7 \mathbf{a}$ & $1637.4 a$ \\
\hline Vegetation biomass (ka ha ${ }^{-1}$ ) & $2318.8 \mathrm{a}$ & $2317.3 a$ & $2161.7 \mathrm{a}$ \\
\hline Soil organic matter $(\%)$ & $6.3 \mathrm{a}$ & $6.5 \mathrm{a}$ & $6.5 \mathrm{a}$ \\
\hline Soil aggregate stability $(\%)$ & $72.3 \mathrm{a}$ & $69.6 a$ & $70.1 \mathrm{a}$ \\
\hline Soil bulk density $\left(\mathrm{Mg} \mathrm{m}^{-3}\right)$ & $0.74 a$ & $0.73 \mathrm{a}$ & $0.73 a$ \\
\hline Microrelief (unitless) & $1.1 \mathrm{a}$ & $1.2 \mathrm{a}$ & $1.1 \mathrm{a}$ \\
\hline
\end{tabular}

'Means followed by the same letter in a row are not significantly different at the $95 \%$ level of significance.
Table 2. Simple correlation coefficients of stocking density and vegetation and soil variables correlated with terminal infiltration rate and sediment production on the Edwards Plateau, Texas.'

\begin{tabular}{lcc}
\hline & \multicolumn{2}{c}{ Dependent Variables } \\
\cline { 2 - 3 } Independent variables & $\begin{array}{c}\text { Infiltration } \\
\text { rate }\end{array}$ & $\begin{array}{c}\text { Sediment } \\
\text { production }\end{array}$ \\
\hline Stocking density & $.08 \mathrm{NS}$ & $-.08 \mathrm{NS}$ \\
Bare ground & -.49 & .49 \\
Rock cover & -.13 & $.08 \mathrm{NS}$ \\
Litter cover & .25 & $-.08 \mathrm{NS}$ \\
Vegetative cover & .31 & -.45 \\
Litter biomass & .17 & -.22 \\
Vegetation biomass & .50 & -.50 \\
Soil organic matter content & $.04 \mathrm{NS}$ & -.18 \\
Soil aggregate stability & .19 & -.35 \\
Soil bulk density & -.09 & $.03 \mathrm{NS}$ \\
Microrelief & .48 & -.33
\end{tabular}

ICorrelation coefficients followed by NS are not significant at the $95 \%$ level of significance.

given much credence (Table 2). Therefore, the analysis of variance remained the best test of the study objectives.

In order to better understand the paradoxical results, an analysis of variance was conducted for each sample period. No consistent trend was evident and it appeared that the third and fourth sample periods in 1984 were disproportionately responsible for the overall significance of treatment differences (Fig. 2). In addition, the
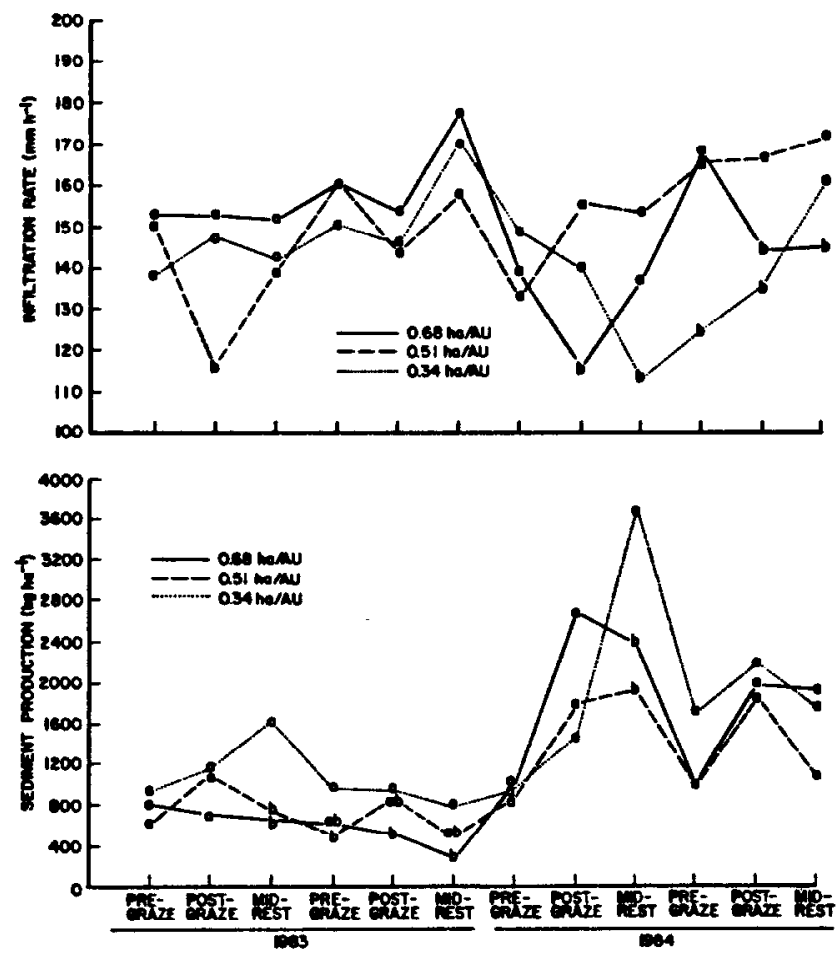

Fig. 2. Mean infiltration rates and sediment production across time for pastures grazed at 3 stocking densities on the Edwards Plateau, Texas. Means for each sample date with the same letter are not significantly different $(\alpha=.05)$.

impact of stocking density should be most apparent in the immediate post-graze condition if high density trampling activity truly provides the hypothesized hydrologic benefits. Such a scenario would create a statistical interaction favoring the preferred stocking density during the immediate post-graze portion of the rotation cycle. No interaction between stocking density and stage of rotation cycle was found. It is, therefore, somewhat doubtful that 
stocking density was a major factor contributing to the differences detected between pastures. Rather, the random selection of a site with significantly poorer hydrologic condition on 1 or 2 occasions may have caused the paradoxical significance between pastures. The occurrence of significant spatial variability in hydrologic parameters on relatively uniform range sites is a common phenomenon (Devaurs and Gifford 1984, Gifford 1984). However, regardless of whether the pasture grazed at the highest stocking density was in poorer or similar hydrologic condition when compared to other pastures in terms of treatment response, these data do not support the hypothesized beneficial hydrologic advantages of increased stocking density via manipulation of pasture size and numbers.

It is true that subdividing pastures of an existing rotational grazing system will result in increased stocking density per pasture during the grazed portion of the rotation cycle. However, one must also consider the length of the period during which grazing occurs. When the number of pastures is increased, the length of the grazing period per pasture must be reduced proportionately in order to avoid overgrazing. The stocking rate or total number of animal unit days (AUD) per unit area remains the same, regardless of the number of pastures. For example, 47 animal units were present on the Sonora grazing system at all times. Under a 56-day rotation cycle, the smallest pasture ( $16 \mathrm{ha}$ ) was grazed for 4 days per cycle giving a total of $11.75 \mathrm{AUD} /$ ha:

$$
(47 \mathrm{AU} \times 4 \text { days }) \div 16 \mathrm{ha}=11.75 \mathrm{AUD} / \mathrm{ha} \text {. }
$$

The largest pasture ( $32 \mathrm{ha}$ ) was impacted to the same degree after a typical 8-day grazing period:

$$
\text { (47 AU } \times 8 \text { days) } \div 32 \mathrm{ha}=11.75 \mathrm{AUD} / \mathrm{ha} \text {. }
$$

The principal difference was the number of days over which the impact occurred. The difference of $\mathbf{4}$ days in this study is probably insignificant in terms of a 56-day rotation cycle. Indeed, the results of this study indicate that, at best, manipulation of stocking density by increasing the number of pastures within an intensive rotational system will do little to modify the hydrologic effects of intensive trampling. Pluhar (1984), likewise, detected no difference in the post-graze hydrologic condition of pastures which represented 14-and 42-pasture rotational grazing systems of equal size, stocked at the same rate, and grazed with a rotation cycle of equal length.

Perhaps of greater importance than the length of the grazing period, is the length of the rest period. Infiltration rate is generally lower and sediment production higher following short periods of intensive grazing associated with rotational grazing system (Pluhar 1984, Smith 1980, Warren 1985, Weltz 1983, Wood and Blackburn $1981 \mathrm{a}, 1981 \mathrm{~b})$. The impact is especially acute during dry or dormant seasons and increases as stocking rate increases (Warren et al. 1986b). In order to avoid long-term progressive degradation, rest periods must be of sufficient length to allow full recovery of the soil hydrologic condition prior to the reoccurrence of livestock impact. It seems logical that any increase in stocking rate must, therefore, be accompanied by an increase in the length of the rest period in order to compensate for the greater impact. Rest should also be increased during seasons of maximum livestock impact (i.e., drought or winter dormancy). In addition, the necessary length of the rest period may be longer in semiarid and arid regions than in more mesic regions.

The potential for increasing the length of the rest period through manipulation of the number of pastures is minimal where the number of pastures is already large. By definition, short-duration grazing systems have a stocking density index $>2$ (Society for Range Management 1974). This requires that the land area available to livestock at any point in time must be less than $50 \%$ of the total land area in the grazing system. For a 1-herd system, the minimum number of pastures to meet the criterion is 3 . The greatest potential for altering the number of rested days occurs where the number of pastures is small. For the 56-day rotation cycle at the

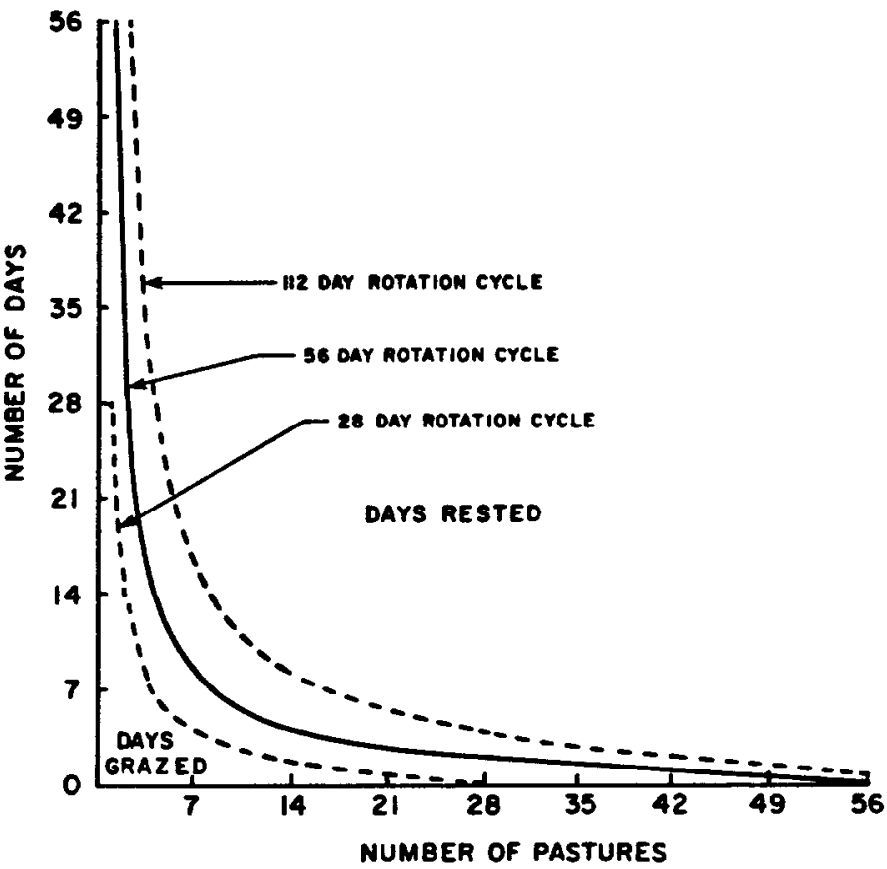

Fig. 3. Days rested (area above line) and days grazed (area below line) as a function of pasture number in a rotational grazing system and to the length of the rotation cycle.

Sonora Station, the maximum potential occurs between 3 and 8 pastures (Fig. 3). Three pastures is the necessary minimum to be classified as a short-duration grazing system, and 7.5 days is the point of inflection on the curve, beyond which the potential for increasing the length of the rest period is minimized. This supports the conclusion that differences in infiltration rate and sediment production between pastures representing 7-, 9-, and 14-pasture short-duration grazing systems in this study were not attributable to stocking density.

Significant alterations in the length of the rotation cycle have little effect on the number of pastures that can be added before reaching the point of inflection. For 28- and 112-day rotation cycles, the point of inflection is reached at 5 and 12 pastures, respectively (Fig. 3). Therefore, regardless of the length of the rotation cycle, altering the number of pastures in an intensive rotational grazing system will probably have little effect on soil hydrologic condition, except where only a few pastures are present.

\section{Literature Cited}

Alderfer, R.B., and R.R. Robinson. 1947. Runoff from pastures in relation to grazing intensity and soil compaction. J. Amer. Soc. Agron. 39:948-958.

Blackburn, W.H. 1984. Impacts of grazing intensity and specialized grazing systems on watershed characteristics and responses, p. 927-983. In: Developing Strategies for Rangeland Management. Nat. Res. Counc./ Nat. Acad. of Sci. Westview Press, Boulder, Colo.

Blackburn, W.H., R.O. Meeuwis, and C.M. Skau. 1974. A mobile infiltrometer for use on rangeland. J. Range Manage. 27:322-323.

Blake, G.R. 1965. Bulk density, p. 374-390. In: C.A. Black (ed), Methods of Soil Analysis, Part I. Amer. Soc. Agron., Madison, Wis.

Branson, F.A., G.F. Gifford, K.G. Renard, and R.F. Hadley. 1981. Rangeland hydrology. Range Sci. Ser. No. 1. Kendall/Hunt Pub. Co., Dubuque, Ia.

Devaurs, M., and G.F. Gifford. 1984. Variability of infiltration within large runoff plots on rangelands. J. Range Manage. 37:523-528.

Gamougoun, N.D., R.P.Smith, M.K. Wood, and R.D. Pieper. 1984. Soil, vegetation, and hydrologic responses to grazing management at Fort Stanton, New Mexico. J. Range Manage. 37:538-541.

Gifford, G.F. 1984. Vegetation allocation for meeting site requirements, $p$ 35-116. In: Developing Strategies for Rangeland Management. Nat. Res. 
Counc./Nat. Acad. of Sci. Westriew Press, Boulder, Colo.

Goodloe, S. 1969. Short duration grazing in Rhodesia. J. Range Manage. 22:369-373.

Kemper, W.D. 1965. Aggregate stability, p. 511-519. In: C.A. Black (ed), Methods of Soil Analysis, Part I. Amer. Soc. Agron., Madison, Wis.

Kincaid, D.R., and G. Williams. 1966. Rainfall effect on soil surface characteristics following range improvement treatments. J. Range Manage. 19:346-351.

Knight. R.W.1980. Hydrologic response of selected grazing systems on the Edwards Plateau. Ph.D. Diss., Texas A\&M Univ., College Station.

McCalla, G.R., W.H. Blackburn, and L.B. Merrill. 1984a. Effects of livestock grazing on infiltration rates, Edwards Plateau of Texas. J. Range Manage. 37:265-269.

McCalla, G.R., W.H. Blackburn, and L.B. Merrill. 1984b. Effects of livestock grazing on sediment production, Edwards Plateau of Texas. J. Range Manage. 37:291-294.

Nelson, D.W., and L.E. Sommers. 1982. Total carbon, organic carbon, and organic matter, p. 539-579. In: A.L. Page (ed), Methods of Soil Analysis, Part 2. Amer. Soc. Agron. Madison, Wis.

Office of Technology Assessment. 1982. Impacts of technology on U.S. cropland and rangeland productivity. Congress of the United States, Washington, D.C.

Pearson, G.A., G.A. Jung, R.E. Fowler, and D.M. Mitchell. 1975. Effects of grazing on infiltration rates and waste water spray fields. Proc. Soil Sci. Soc. Amer. 29:954-957.

Pluhar, J.J. 1984. Hydrologic impacts of selected grazing systems on the Texas Rolling Plains. M.S. Thesis, Texas A\&M Univ., College Station.

Rauzi, F., and C.L. Hanson. 1966. Water intake and runoff as affected by intensity of grazing. J. Range Manage. 19:351-356.

Rhoades, E.D., L.F. Locke, H.M. Taylor, and E.H. McIlvain. 1964. Water intake on a sandy range as affected by 20 years of differential cattle stocking rates. J. Range Manage. 17:185-190.

Roundy, B.A., J.A. Young, G.J. Cluff, and R.A. Evans. 1983. Measurement of soil water on rangelands. USDA Agr. Res. Serv. Agr. Res. Results, Western Ser.
Savory, A. 1978. A holistic approach to ranch management using short duration grazing, p. 555-557. In: Proc. of the 1st Internat. Range Cong., Soc. Range Manage., Denver, Colo.

Savory, A. 1983. The Savory grazing method or holistic resource management. Rangelands 5:155-159.

Savory, A., and S.D. Parsons. 1980. The Savory grazing method. Rangelands 2:234-237.

Smith, R.P. 1980. The influence of different grazing practices on infiltration rates and sediment production at Fort Stanton, New Mexico. M.S. Thesis, New Mexico State Univ., Las Cruces.

Snedecor, G.W., and W.C. Cochran. 1967. Statistical methods. Iowa State Univ. Press, Ames.

Society for Range Management, Range Term Glossary Committee. 1974. A glossary of terms used in range management. Denver, Colo.

Steel, R.G.D., and J.H. Torrie. 1980. Principles and procedures of statistics. McGraw-Hill Book Co., New York.

Thurow, T.L. 1985. Hydrologic interrelationships with vegetation and soil as affected by selected livestock grazing systems and climate on the Edwards Plateau. Ph.D. Diss., Texas A\&M Univ., College Station.

Voisin, A. 1959. Grass productivity. Philosophical Library, Inc. New York.

Walker, J.W., and R.K. Heitschmidt. 1986. Effect of various grazing treatments on type and density of cattle trails. J. Range Manage. 39:

Walter, J. 1984. Rangeland revolutionary: An interview with Allan Savory. J. Soil and Water Conserv. 29:235-240.

Warren, S.D., W.H. Blackburn, and C.A. Taylor, Jr. 1986a. Effects of season and stage of rotation cycle on hydrologic condition of rangeland under intensive rotation grazing. J. Range Manage. 39:486-491.

Warren, S.D., T.L. Thurow, W.H. Blackburn, and N.E. Garza. 1986b. The influence of livestock trampling under intensive rotation grazing on soil hydrologic characteristics. J. Range Manage 39:491-495.

Weltz, M. 1983. The influence of short duration and continuous grazing on infiltration rate and sediment yield in southcentral New Mexico. M.S. Thesis, New Mexico State Univ., Las Cruces.

Wood, M.K., and W.H. Blackbum. 1981a. Grazing systems: Their influence on infiltration rates in the Rolling Plains of Texas. J. Range Manage. 34:331-335.

Wood, M.K., and W.H. Blackburn. 1981b. Sediment production as influenced by livestock grazing in the Texas Rolling Plains. J. Range Manage. 34:228-231.

\section{Third International Rangeland Congress To Be Held in New Delhi, India, in 1988}

Plans for the 3rd IRC are being reorganized with excellent support from the Government of India. The meeting date has been postponed one year to allow mailing of the first notice well in advance of the Congress. The date is expected to be in the month of November, 1988.

Look for more details concerning the 3rd IRC in upcoming issues of Rangelands. Please pass this information on rescheduling of the meeting to universities and all others interested in rangeland management. 